\title{
Thermodynamic Refractory Corrosion Model for Ferronickel Manufacturing
}

\author{
CHRISTOPH SAGADIN, STEFAN LUIDOLD, CHRISTOPH WAGNER, \\ CHRISTOPH PICHLER, DANIEL KREUZER, ALFRED SPANRING, \\ HELMUT ANTREKOWITSCH, AMY CLARKE, and KESTER CLARKE
}

\begin{abstract}
A thermodynamic model, based on SimuSage, was developed to simulate refractory corrosion between a magnesia-based refractory material and ferronickel (FeNi) slags. The model considers a theoretical cross-section of a refractory material to simulate a ferronickel smelter application. The current model is structured into 10 zones, which characterize different sectors in the brick (hot to cold side) perpendicular to the refractory surface with an underlying temperature gradient. In each zone, the model calculates the equilibrium between the slag and a specified amount of refractory material. The emerging liquid phases are transferred to subsequent zones. Meanwhile, all solids remain in the calculated zone. This computational process repeats until a steady state is reached in each zone. The simulation results show that when FeNi slag infiltrates into the refractory material, the melt dissolves the magnesia-based refractory and forms silicates $(\mathrm{Mg}, \mathrm{Fe}, \mathrm{Ca})_{2} \mathrm{SiO}_{4}$ and $\mathrm{Al}$ spinel $\left((\mathrm{Mg}, \mathrm{Fe}) \mathrm{Al}_{2} \mathrm{O}_{4}\right)$. Furthermore, it was observed that iron oxide from the slag reacts with the refractory and generates magnesiowustite $(\mathrm{Mg}, \mathrm{Fe}) \mathrm{O}$. Practical lab-scale tests and scanning electron microscopy (SEM)/Energy Dispersive X-ray Spectroscopy (EDS) characterization confirmed the formation of these minerals. Finally, the refractory corrosion model (RCM) ultimately provides a pathway for improving refractory lifetimes and performance.
\end{abstract}

https://doi.org/10.1007/s11663-021-02077-x

(C) The Author(s) 2021

\section{INTRODUCTION}

HIGH chemical refractory stability constitutes an essential factor in the pyrometallurgical industry. The corrosion of refractory materials in metallurgical processes, which is caused by slags, metals and gases, massively influences furnace lifetimes. Therefore, it is necessary to reduce removal of refractory to guarantee safe furnace operation, satisfy furnace lifetimes, and ensure short downtimes. ${ }^{[1-3]}$

CHRISTOPH SAGADIN and STEFAN LUIDOLD are with the CD-Laboratory for Extractive Metallurgy of Technological Metals, Nonferrous Metallurgy, Montanuniversitaet Leoben, Leoben, 8700, Austria. Contact e-mail: christoph.sagadin@alumni.unileoben.ac.at. CHRISTOPH WAGNER, CHRISTOPH PICHLER, DANIEL KREUZER, and ALFRED SPANRING are with the RHI Magnesita, Industrial Projects, Vienna, 1120, Austria. HELMUT ANTREKOWITSCH is with the Nonferrous Metallurgy, Montanuniversitaet Leoben, Leoben, 8700, Austria. AMY CLARKE and KESTER CLARKE are with the Metallurgical and Materials Engineering, Colorado School of Mines, 1500 Illinois St., Golden, CL, USA.

Manuscript submitted May 4, 2020; accepted January 2, 2021.

Article published online February 24, 2021.
The chemical reactivity of liquid slags consisting of ions is critically important for metallurgical processes. According to Lee and Zhang, a four-stage process describes the deterioration of refractory materials: wetting, penetration due to porosity, disruption of the refractory bonds by chemical reactions, and finally the erosion of the refractory constituents by fluent liquids. Otherwise, Song et $a l^{[4]}$ characterized the corrosion process of $\mathrm{Al}_{2} \mathrm{O}_{3}$ refractory by slag via three stages: melting and wetting, dissolution and diffusion, as well as crystallization. Bennett et al. ${ }^{[5]}$ specified the deterioration of the primarily refractory lining as an interaction of chemical dissolution at the slag / refractory interface, chemical spalling at the interface, and a structural spalling caused by molten slag penetration into the refractory. Lee et al. ${ }^{[6]}$ reported that micro-cracks as well as small pores are the main channels of initial penetration. Han ${ }^{[7]}$ described the effect of temperature on the infiltration depth in his publication. A higher temperature causes deeper penetration of the slag into the refractory material. Therefore, the right choice of refractory with high corrosion and erosion resistance represents one of the critical requirements to prevent or minimize such adverse effects. ${ }^{[6]}$ 
Usually, the knowledge of refractory corrosion is based on empirical observations and corrosion studies with the help of static and dynamic corrosion tests. To examine the thermochemical processes of refractory materials in metallurgical furnaces, thermodynamic calculations are required. Several corrosion models ${ }^{[8-11]}$ use thermodynamic data from the software FactSage ${ }^{\mathrm{TM}}$, in combination with practical investigations. The aim of corrosion simulations focuses on the corrosion of refractory materials caused by slags. For thermodynamic simulations, a simplification of chemical systems by the selection of main oxides is required for the calculations. ${ }^{[9-13]}$

Figure 1 presents a corrosion simulation model, which is used in several studies, thereby a defined amount of slag (S) theoretically infiltrates in zone 1 and reacts with the same amount of refractory (R). A thermodynamical calculation computes the products depending on the chemical composition of the components, by using FactSage ${ }^{\mathrm{TM}}$. All calculations are executed at constant temperature and pressure. After the first reaction step, the resulting melt $1\left(\mathrm{M}_{1}\right)$ enters the next zone and reacts again with the same amount of refractory material. This procedure repeats until the simulated amount of the solid phases reaches a constant value. The thermodynamic calculations in the zones are as follows: ${ }^{[11,14]}$

$$
\begin{aligned}
\text { Zone } 1 & : x g \text { Slag }+x \text { g Refractory } \\
& \rightarrow \text { Melt }_{1}+\text { Solid Oxides }_{1}
\end{aligned}
$$

$$
\begin{aligned}
\text { Zone 2-10 } & : x \text { g Melt }_{i-1}+x \text { g Refractory }_{i} \\
& \rightarrow \text { Melt }_{i}+\text { Solid Oxides }_{i}
\end{aligned}
$$

$\operatorname{Han}^{[7]}$ investigated the penetration of slag at different temperatures, but without suggestion of a corrosion model. Han et al. ${ }^{[15]}$ describe a corrosion model that consists of nine equilibrium zones, with a decreasing slag / refractory ratio from zone 1 to zone 9 (Zone $\mathrm{n}:(1-\mathrm{n}$ / 10) g slag resp. melt $+(0+\mathrm{n} / 10)$ g refractory $)$, but without consideration of temperature differences.

This paper presents a refractory corrosion model (RCM) developed by using the software packages SimuSage $^{\mathrm{TM}[16]}$ and FactSage $7.3^{\mathrm{TM}[17]}$ (used databases FactPS and FToxid). The combination enables the creation of a program to simulate the corrosion of refractory material by liquid slag. The great advantage of the described corrosion model is the investigation of local corrosion of the refractory material. It considers the shift of the liquid phase's chemical composition during its way from the outside (initial slag) through the individual zones of the refractory. In addition, the free pore volume of the refractory is also taken into account, which represents the main reason of infiltration. ${ }^{[6]}$ The consideration of the temperature gradient in the refractory and selectable amounts of liquid phase and refractory for the equilibrium calculations in each zone are only some advantages of this simulation model. Beside, an adaptation of the simulation model to different slags/refractory systems is possible in a quick and easy way. The compiled application allows the determination of corrosion for different chemical composition of refractory and slag at the ferronickel production. For this purpose, the RCM was tested to investigate the corrosion behavior between magnesia-based refractory and ferronickel slags. Evaluations of the phases formed and chemical compositions of the different zones in the refractory brick were also performed. The tests and results, combined with RCM and practical measurements in laboratory-scale trials,

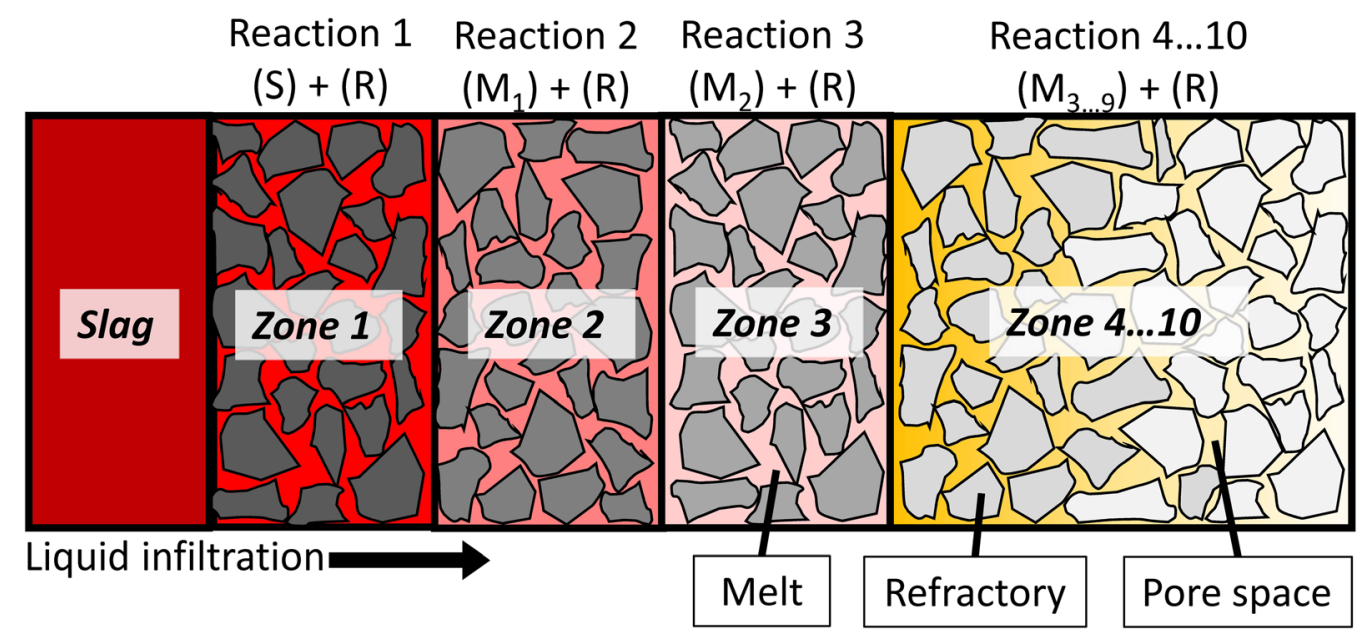

Fig. 1-Demonstration of liquid slag (S) infiltration into porous refractory material (R) (refractory brick) and reactions of slag with refractory during the infiltration ${ }^{[9,11,14]}$ 
expand the knowledge of actual corrosion mechanisms, which is necessary for improved refractory performance and extended lifetimes.

\section{MODEL STRUCTURE AND FUNCTION}

\section{A. Corrosion Procedure}

The RCM simulates the corrosion of refractory affected by slags along a theoretical, open pore. Figure 2 depicts the structure of the model including 10 zones with each of them having a defined amount of refractory material and a virtual pore which has no special shape or size but a present share of the volume of each zone.

Process slag (Slag) penetrates the pore in zone 1, reacts, and then dissolves parts of the refractory. When slag and refractory come into contact, solid oxides and melt are formed. The solid oxides (Solid Oxides 1) remain in zone 1 and the melt (Melt 1) is passed on to zone 2, where a similar process occurs. Solid Oxides 2 and Melt 2 appear as products in zone 2, and Melt 2 then enters zone 3 . This process continues up to zone 10 . If there is complete solidification of the melt in an earlier zone, transport of the melt to subsequent zones and further reactions become impossible. Fresh slag continues to penetrate, but into already corroded zones such as zone 1. A negative temperature gradient from zone 1 to zone 10 provides an equilibrium calculation at decreasing temperatures from the slag side to the inside of the refractory.

The definition of a single zone is given as follows:

$$
m_{\mathrm{R}}+m_{\mathrm{P}}+m_{\mathrm{M}}+m_{\mathrm{SO}}=1 g\left(m_{\mathrm{T}}\right)
$$

$m_{\mathrm{R}}$ is total mass of unreacted refractory in a zone, $m_{\mathrm{P}}$ is mass of the absorption capacity for slag/melt and solid oxides in the pore, $m_{\mathrm{M}}$ is mass of melt in a zone (before the first calculation $m_{\mathrm{M}}=0$ ), $\mathrm{m}_{\mathrm{SO}}$ is mass of solid oxides in a zone (before the first calculation $m_{\mathrm{SO}}$ $=0)$, and $\mathrm{m}_{\mathrm{T}}$ is total mass of zone in $\mathrm{g}$.

\section{B. Zone Description}

The RCM consists of ten similar zones, where each one contains several calculation modules and material flows. Figure 3 illustrates the calculation schema of one zone in the model, which serves for all zones. The refractory amount that reacts with slag/melt is determined by the amount of liquid in the respective zone and a factor (refractory reaction part) specified via the input mask of the application. That means for each calculation cycle a small part of the refractory reacts with the melt, which reduces the total amount of unreacted refractory in a zone. First, the thermodynamic equilibrium of incoming streams (slag/melt and refractory) at a defined temperature is calculated. The result comprises a mixture of oxidic melt and solid oxides, which are separated in the "Phase Splitter". The melt enters the "Melt Splitter" which calculates the melt volume distribution between melts $\mathrm{A}$ and $\mathrm{B}$, depending on the free pore volume in the next zone. Meanwhile, the solid oxides remain in the zone. Each zone exhibits a present refractory porosity, which indicates the maximum volume of slag/melt that can enter the zone, whereas the balance remains in the previous zone. At the beginning, the porosity of each zone has the same value specified via the input mask; during the calculations, the free pore volume of the zones can change because of mass variation of solid oxide, melt, and refractory. $\left(m_{\mathrm{P}}=\right.$ $\left.1 \mathrm{~g}\left(m_{\mathrm{T}}\right)-m_{\mathrm{SO}}-m_{\mathrm{M}}-m_{\mathrm{R}}\right)$.

The melt splitter calculates the real volume of melt $\mathrm{A}$, which is equal or less than the volume of the melt in that zone and the pore volume in the next zone. Melt A exits that zone and enters the following zone, while melt B remains in the respective zone. If the calculations for all zones are completed, the process repeats by calling the Iterator, which updates all values (porosity, amount of unreacted refractory, solid/liquid reaction products, etc.) for each zone prior to the start of the next calculation cycle by the transfer of fresh slag into zone 1.

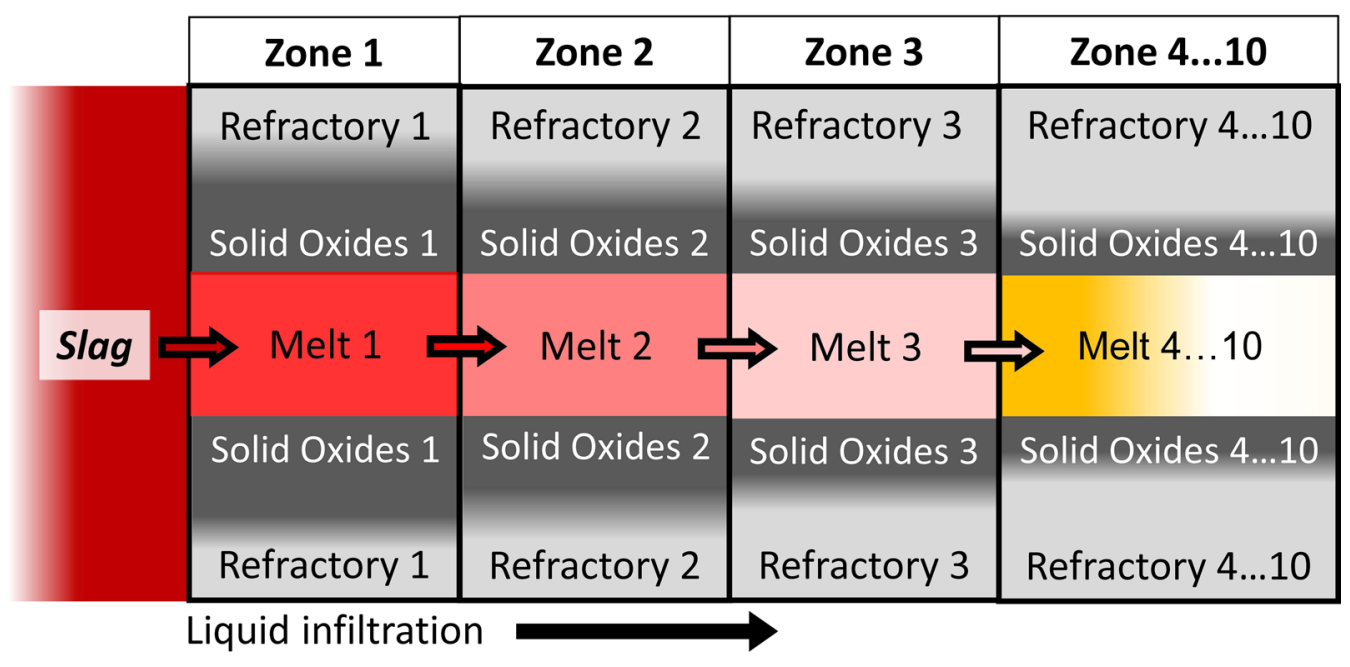

Fig. 2-Schematic structure of the refractory corrosion model with the zones (possible composition: unreacted refractory, free pore space (absorption capacity), solid oxides and melt); each zone depicts the refractory where the pore is located, which is already at least partially filled up with melt and the solid reaction product; solid oxides are situated around the pore. The size of each zone is indirectly defined by the temperature decline from one zone to the other. 


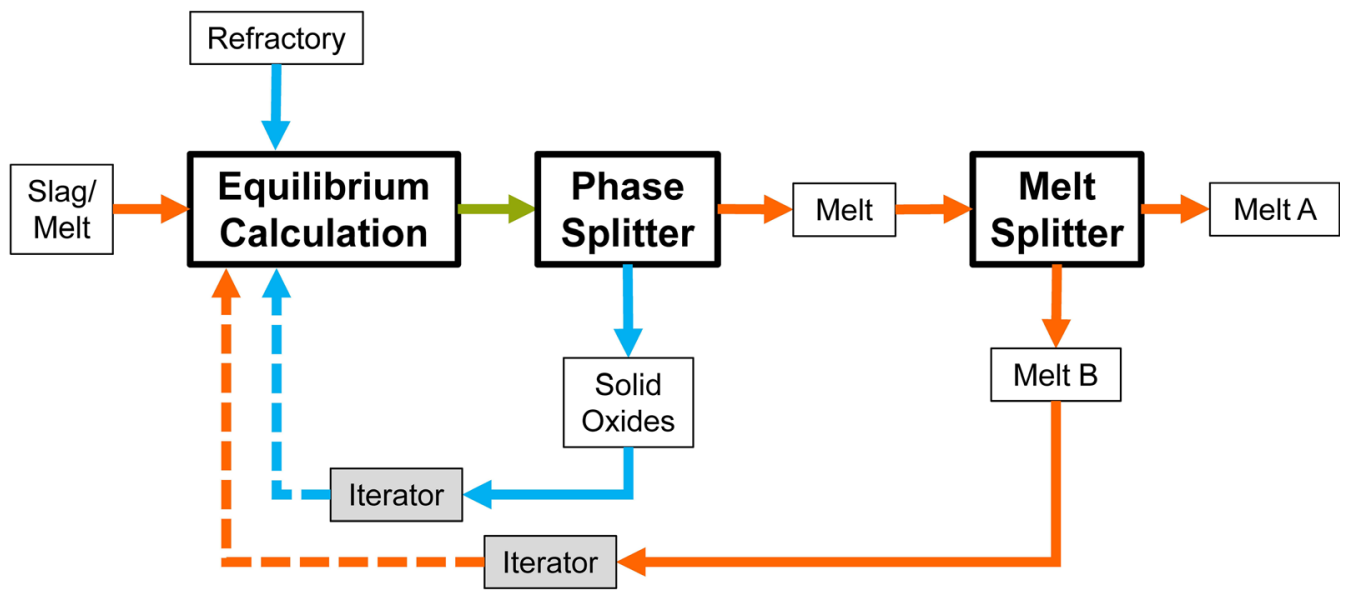

Fig. 3- Calculation schema for each zone of the refractory corrosion model.

This procedure goes on until the selected stop criterion occurs. The latter can be chosen from the options "the entire amount of refractory in zone 1 is consumed by reaction", "a steady state is reached", or "the specified number of calculation cycles are processed".

\section{Program Parameters and Stop Criterion}

The RCM provides variable inputs of model parameters like chemical composition of the refractory and slag, refractory porosity, and temperature gradient in the corrosion zone. Moreover, the model can differentiate between coarse and fine grains (fine grains react faster than coarse $\mathrm{e}^{[6,7]}$; the classification of the grain size depends on the refractory), considering chemical composition. To simulate a faster dissolution of the binder phases ${ }^{[6]}$ which consist of fine grains, a differentiation between refractory base material and binder is possible. In addition, the porosity of the refractory constitutes an essential parameter for the calculations and determines the maximum amount of liquid, which can enter the respective zone. In the simulation example, the refractory bricks exhibit a certain porosity. Moreover, the parameter "refractory reaction part" describes the amount of refractory, which enters the equilibrium calculation in each cycle. Therefore, this parameter serves for a rough consideration of the strongly limited diffusion in solid phases that hinders the total mass of refractory within the respective zone to take part in reactions toward thermodynamic equilibrium. This value is indicated in relation to the amount of liquid phase in the zone and, therefore, qualitatively represents geometrical and other parameters (size of reaction interface, pore size and distribution, diffusion rate, time...). Also a stepwise declining temperatures $\left[T_{\text {Step }}=\left(T_{10}-T_{1}\right) / 9\right]$ will be applied from zone 1 to zone 10 inside the refractory lining by specification of the temperatures in zones 1 and 10. In the following calculation, the equilibrium temperature from zone 10 was chosen in such a way that the whole melt is solidified to prevent physically absurd situations by the extinction of material from the system.
The following Table I shows the parameters applied for the subsequently presented calculations. With the temperature input parameters, the equilibrium temperatures of the zones were calculated. The porosity of 15 pct calculates the mass of absorption capacity of the refractory $\left(m_{\mathrm{P}}=1 \mathrm{~g}\left(m_{\mathrm{T}}\right) \times R_{\mathrm{pct} \mathrm{P}}\right)$. The subdivision into two grain size fractions enables a more precise description of the refractory material. The table shows that the refractory material consists of 100 pct coarse material. The refractory amount for the equilibrium calculation is defined as: $m_{\mathrm{RPC}}=m_{\mathrm{M}} \times R_{\mathrm{pct}} \mathrm{RPC}$. These parameters are also used to calculate the remaining unreacted refractory material: $m_{\mathrm{RC} / \mathrm{RF}}=$ $\left(m_{\mathrm{R}} \times R_{\text {pct C/Pct F }}\right)-m_{\mathrm{RPC} / \mathrm{RPF}}$. If no unreacted refractory material is available anymore because of the corrosion, the whole zone consists of melt and formed solid oxides.

The model enables the calculation of different stages of corrosion, which are defined by the stop criterion, where the calculation ends, and the results are provided. The RCM user can choose between the following stop criterions: stop when the refractory in zone 1 is used up, stop when the zones are in equilibrium, or stop after a defined number of calculation steps.

\section{RESULTS OF THERMODYNAMIC MODEL CALCULATION}

$\mathrm{SiO}_{2}, \mathrm{MgO}, \mathrm{FeO}$, as well as $\mathrm{Fe}_{2} \mathrm{O}_{3}, \mathrm{CaO}$, and $\mathrm{Al}_{2} \mathrm{O}_{3}$ are the primary oxides of the slag applied in the simulation model (i.e., composed of 46 pct $\mathrm{SiO}_{2}, 18.4$ pet $\mathrm{MgO}, 27.6$ pet $\mathrm{FeO}, 4$ pet $\mathrm{CaO}$ and 4 pet $\mathrm{Al}_{2} \mathrm{O}_{3}$ in the presented example; all $\mathrm{Fe}$ was considered as $\mathrm{FeO}$ due to the reducing conditions in the $\mathrm{FeNi}$ reduction process). However, the corrosion test applied the corresponding amount of $\mathrm{Fe}_{2} \mathrm{O}_{3}$ in the feed and a reductive atmosphere $\left(\mathrm{CO} / \mathrm{CO}_{2}\right.$ mixture). The refractory is a magnesia brick with 97 pct $\mathrm{MgO}, 2$ pet $\mathrm{CaO}$, and 1 pct $\mathrm{SiO}_{2}$, which is commonly used in the production of ferronickel. 
Table I. Applied Model Parameter for a Closer Description of the Refractory Material and Corrosion Zone in the Presented Example

\begin{tabular}{lccc}
\hline Parameter & Abbreviation & Value & Unit \\
\hline Temperature zone 1 & $T_{1}$ & 1600 & ${ }^{\circ} \mathrm{C}$ \\
Temperature zone 10 & $T_{10}$ & 1200 & ${ }^{\circ} \mathrm{C}$ \\
Refractory porosity & $R_{\text {pct P }}$ & 15 & pct \\
Refractory reaction part: coarse grains & $R_{\text {pct RPC }}$ & 10 & pct \\
Refractory reaction part: fine grains & $R_{\text {pct RPF }}$ & 0 & pct \\
Share of coarse grains & $R_{\text {pct C }}$ & 100 & pct \\
Share of fine grains & $R_{\text {pct F }}$ & 0 & pct \\
\hline
\end{tabular}

The thermodynamic evaluation of stable phases in the slag/refractory contact range with SimuSage ${ }^{\mathrm{TM}[16]}$ is a main focus of this research.For this purpose, the compiled model includes all phases and pure substances existing the databases FactPS and FToxid for the system $\mathrm{Al}-\mathrm{Ca}-\mathrm{Fe}-\mathrm{Mg}-\mathrm{Si}-\mathrm{O}$ including the gas phase as well as the database FToxid incorporated immiscibilities. The only exceptions are duplicates, which are only selected once as given as default by FactSage. The corrosion phase model ranges from the slag infiltration zone $1\left(1800^{\circ} \mathrm{C}\right)$ to the cooler zone 10 (inside the refractory; $1200{ }^{\circ} \mathrm{C}$ ). The calculation was performed by utilizing process and refractory data from an industrial ferronickel smelter. Figure 4 highlights a corrosion result from the refractory corrosion model by complete consumption of zone 1 after 30 calculation steps. The highly acidic slag penetrates the refractory and forms various stable phases. A complete transformation of refractory into melt and metal oxide $(\mathrm{MeO})$ occurred in zone 1 . Zones 3 to 9 contain olivine, which represent the main transformation product next to $\mathrm{MeO}$. The small olivine peak at zone 9 can be interpreted as a result of the complete solidification of the remaining melt, which is mostly transformed into olivine. Zone 6 to 9 also contain small amounts of spinel.

Reactions between melt and refractory only take place in the first 9 zones by the formation of new melt and solid oxides. Because of the high content of olivine in Zone 4 filling up any pore space after 30 time steps, it is impossible for the melt to pass from now on and consequently further corrosion just takes place from zone 1 to 3 .

The temperature steps (red dots) in the calculated refractory brick are indicated in Figure 4.

Figure 5 depicts the thermodynamic stable element distributions for the phases in the corrosion graph, calculated by the RCM. Graph A highlights the amount of $\mathrm{Mg}, \mathrm{Fe}, \mathrm{Ca}$, and $\mathrm{Si}$ in the refractory, which contains about 10 pet $\mathrm{Fe}$ in zone 1. The $\mathrm{Mg}$ amount is divided up in the $\mathrm{Mg}$ in $\mathrm{MeO}$ and the $\mathrm{Mg}$ in the unreacted refractory (UR). This value decreases down to 1 pct in zone 9. Zone 3 to 10 show a Ca content of about 3 pct, which was dissolved in other phases. In cooler zones (2-9) where corrosion occurred, a stability of Si can be observed in monoxide phases (refractory). Graph B shows elements like $\mathrm{Si}, \mathrm{Mg}, \mathrm{Fe}$, and $\mathrm{Ca}$ in the stable phase olivine $(\mathrm{Mg}, \mathrm{Ca}, \mathrm{Fe})_{2} \mathrm{SiO}_{4}$. The content of $\mathrm{Ca}$ and $\mathrm{Fe}$ increases from zone 3 to zone 9. Graph $\mathrm{C}$ illustrates the composition of the slag (melt), in which increasing contents of $\mathrm{Fe}$ and $\mathrm{Ca}$ can be observed. It should be emphasized that the total slag amounts in zone 4 up to zone 8 exhibit small enough values that they are not observable in Figure 4. Finally, Graph D depicts the spinel phase $(\mathrm{Mg}, \mathrm{Fe}) \mathrm{Al}_{2} \mathrm{O}_{4}$ in the stable zones 7 to 9 , with high contents of $\mathrm{Al}$.

Figure 6 shows different time steps of the corrosion process calculated by RCM. The solid oxides include stable solid phases like metal oxide, olivine, and spinel. Graph A shows that in the beginning of the corrosion process, most of the unreacted refractory is still available. At first, a barrier of solid oxides appear in zone 4, which prevents a deeper penetration of oxide melt (B) into the refractory. A great example of the barrier formed by solid oxides is shown in Graph $\mathrm{C}$, where the corrosion occurs from zone 1 to zone 3 . The melt cannot penetrate zone 4 , so no corrosion with fresh melt takes place in deeper areas. Graph D shows the situation where zones 1 and 2 completely consist of melt and solid oxides. At the same time, only a part of the refractory in zone 3 reacted to melt and solid oxides, whereas zones 4 to 10 again remained unaffected.

\section{SEM/EDS CORROSION EVALUATION}

In addition to the refractory corrosion model, microstructure investigations were carried out by SEM/EDS. For practical corrosion tests, a synthetic slag was produced, which consists of the main oxides specified in Figure 5. The corrosion test was carried out in a Hot Stage Microscope (HSM), which is usually used to investigate the melting behavior of different materials. Therefore, the synthetic slag powder was pressed into a 3 -mm-high and $3 \mathrm{~mm}$ diameter slag cylinder and was positioned on a small magnesia refractory substrate. With a controlled heating rate of $10 \mathrm{~K} / \mathrm{min}$, the sample was heated up to $1650{ }^{\circ} \mathrm{C}$. The slag cylinder melted, infiltrated the substrate, and reacted with the magnesia-based refractory. One hour after reaching the required temperature, the furnace was switched off and cooled down to room temperature. After the corrosion test, the sample was embedded in a two-component resin (resin with hardener, Araldite DBF) and cut in cross-section by a diamond-cutting wheel. By grinding with different SiC papers (800, 1200, 2400 and 4000), a smooth sample surface was achieved. ${ }^{[3]}$ 


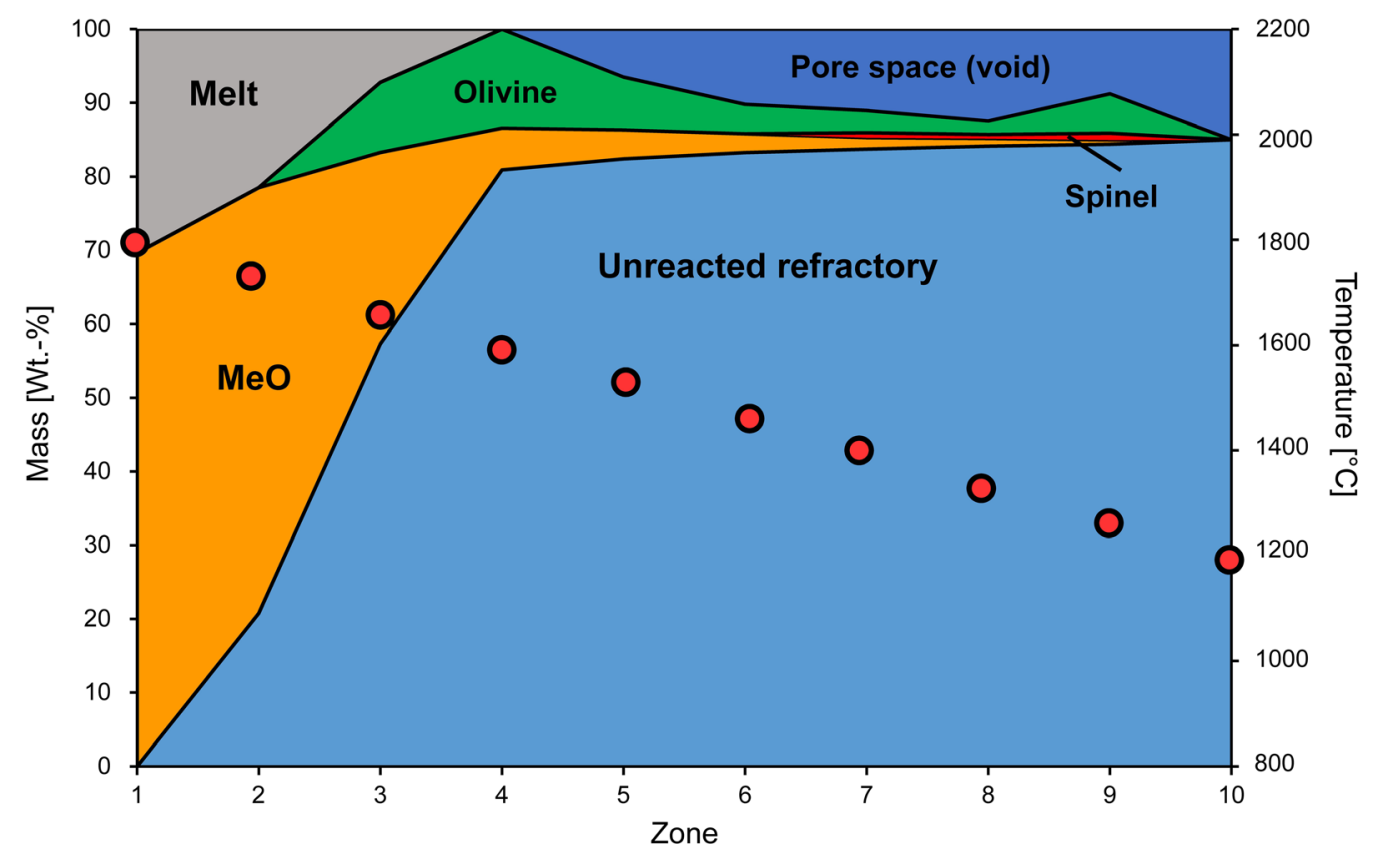

Fig. 4 Corrosion graph for zones 1 to $10\left(1800{ }^{\circ} \mathrm{C}\right.$ to $1200{ }^{\circ} \mathrm{C}$, red dots) with the regions of melt, solid oxides (MeO, olivine, spinel), unreacted refractory, and pore spaces (absorption capacity for melt/solid oxides). The following assumptions were made: slag: 46 pct $\mathrm{SiO}_{2}, 18.4$ pct $\mathrm{MgO}$, 27.6 pct $\mathrm{Fe}_{2} \mathrm{O}_{3}, 4$ pct $\mathrm{CaO}$, and 4 pet $\mathrm{Al}_{2} \mathrm{O}_{3}$; high magnesia refractory: 97 pct $\mathrm{MgO}, 2$ pet $\mathrm{CaO}$, and 1 pet $\mathrm{SiO}_{2}$; and 30 calculation steps (time steps) (Color figure online).
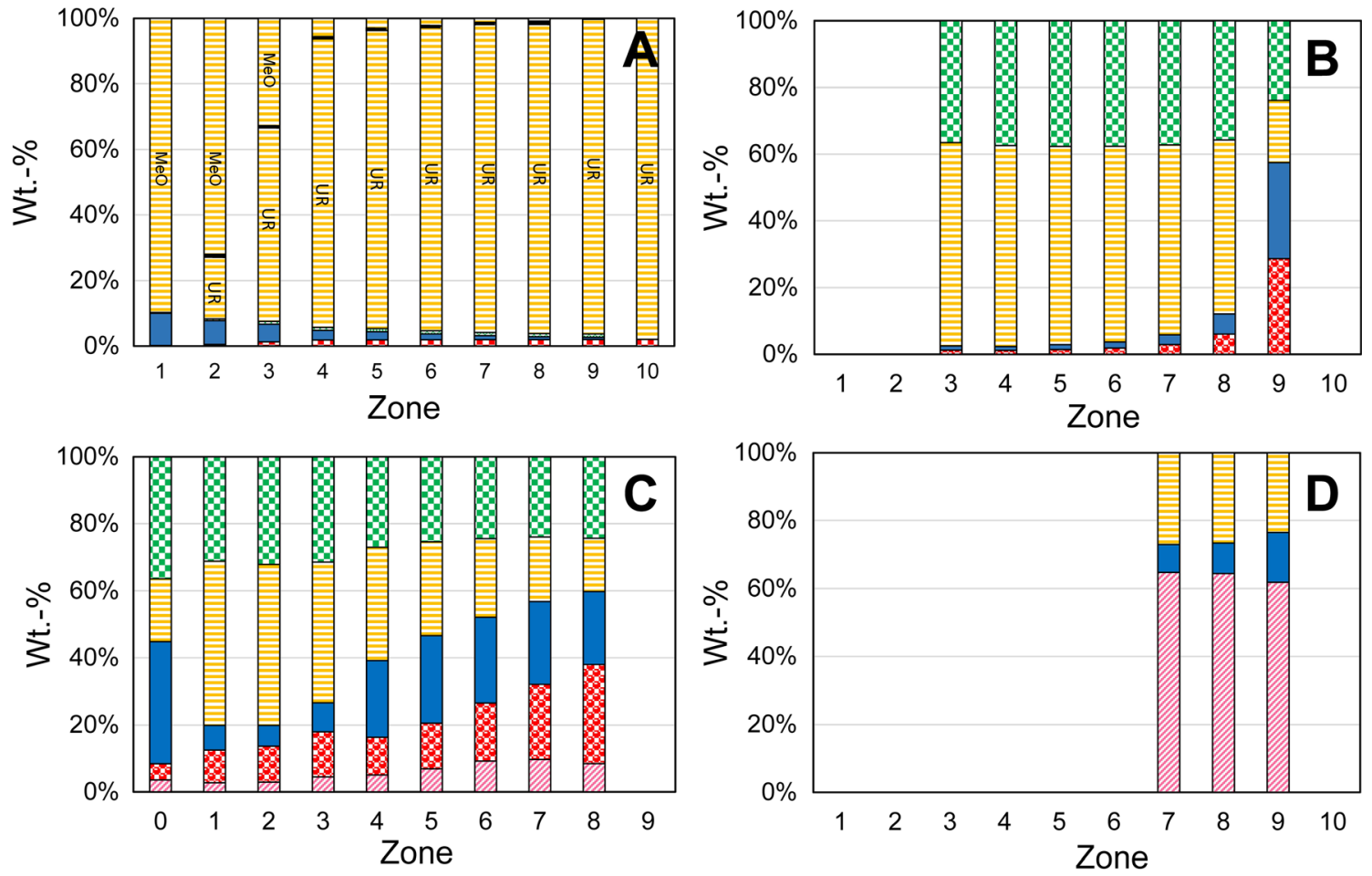

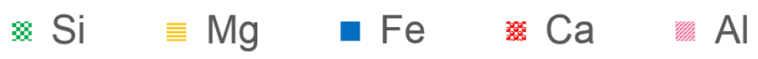

Fig. 5-Distribution of the elements $\mathrm{Fe}, \mathrm{Mg}, \mathrm{Si}, \mathrm{Ca}$, and $\mathrm{Al}$ within the phases olivine, monoxide (MeO), slag (melt), and spinel in the corrosion zone, obtained from phase evaluation of the corrosion graph. The following assumptions were made: A: refractory (monoxide (MeO) + unreacted refractory (UR)), B: olivine, C: liquid slag (zone $0 \rightarrow$ slag composition), and D: spinel; 30 calculation steps. 

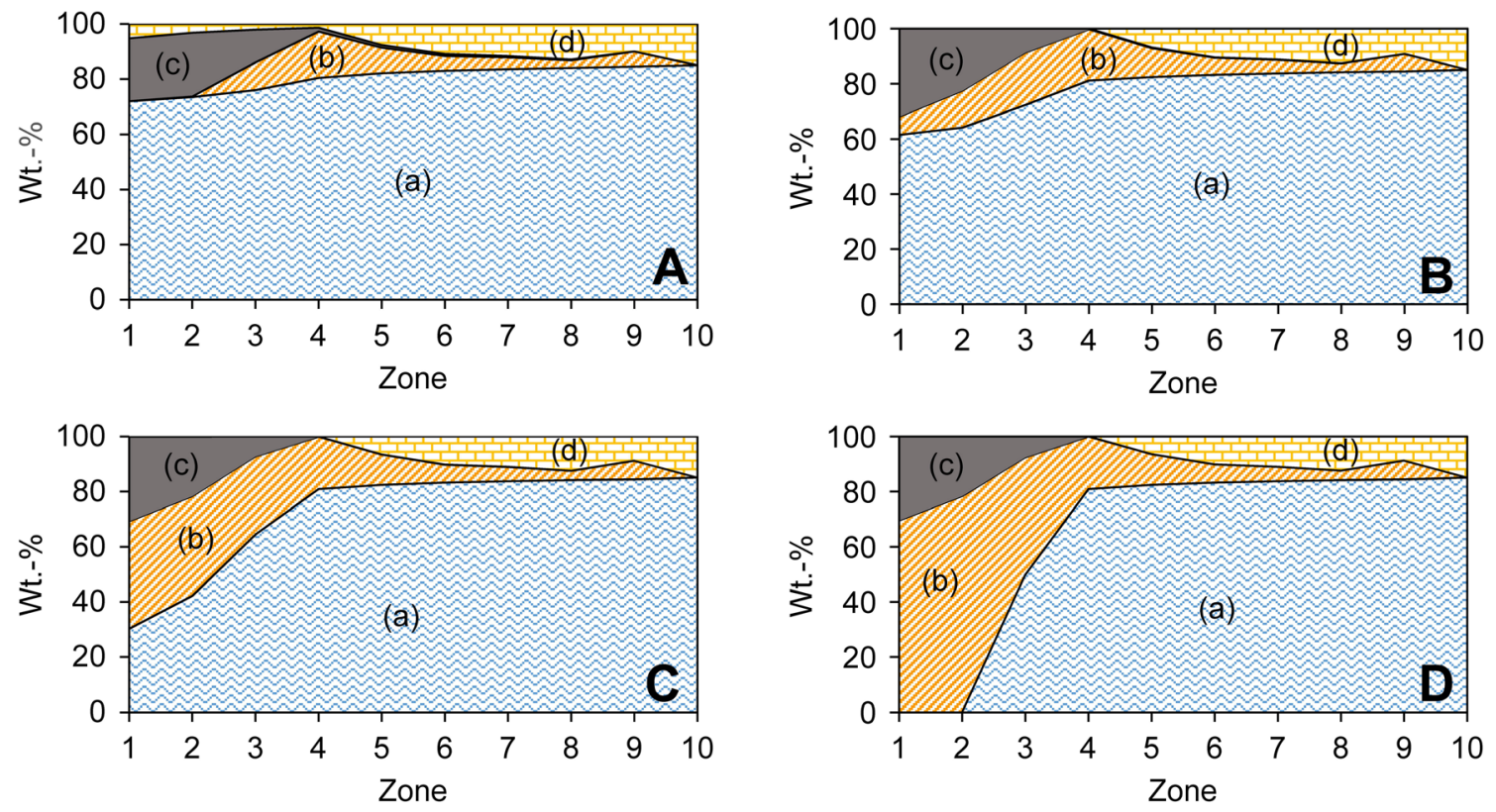

Fig. 6 - Time-dependent corrosion for A: 5 steps, B: 10 steps, C: 20 steps, and D: 40 steps. The $(a)$ blue area indicates unaffected refractory, $(b)$ orange indicates solid oxides, $(c)$ gray indicates melt, and $(d)$ yellow indicates pore (Color figure online).

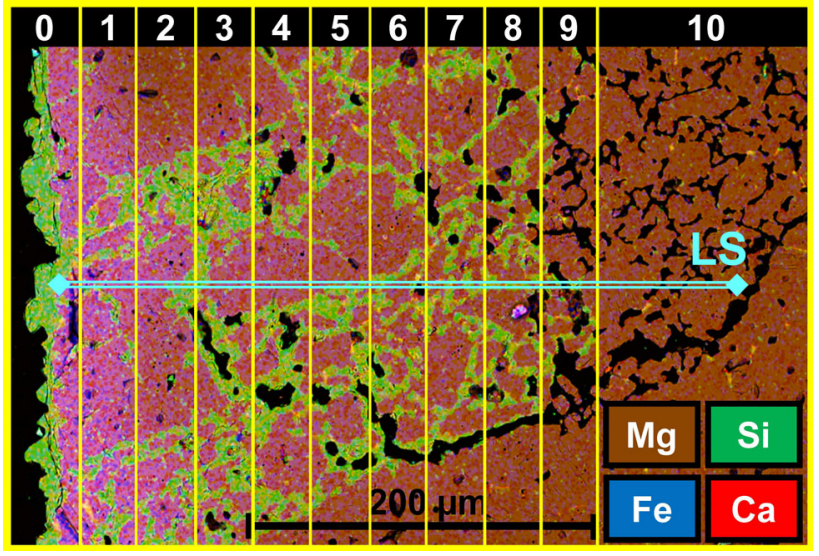

Fig. 7-SEM/EDS mapping of the slag/refractory corrosion area, with the corrosion zones and an executed line scan (LS); distance between two measured points: $2 \mu \mathrm{m}$ - the results of which are shown in Figure 8.

Figure 7 illustrates the sections within the corrosion zone, which reach from the slag to the unaffected refractory. The subdivision of the corroded area across 10 zones serves for comparison with the RCM. Zone 0 , which is not a part of the model, represents the surface of the refractory sample with the embedding material and solid slag. As specified by the line scan in Figure 8, the purple areas in the zones, which are very close to the slag interface, signal a high iron content in the undissolved refractory grains, which constitute magnesiowustite. Magnesia grains with low iron content are located in deeper areas of the refractory (zones 6-10). Silicate phases (green areas) occur between refractory grains (zones 1-9). In zones 1 and 2, the melt filled almost the entire void in the refractory, except for some

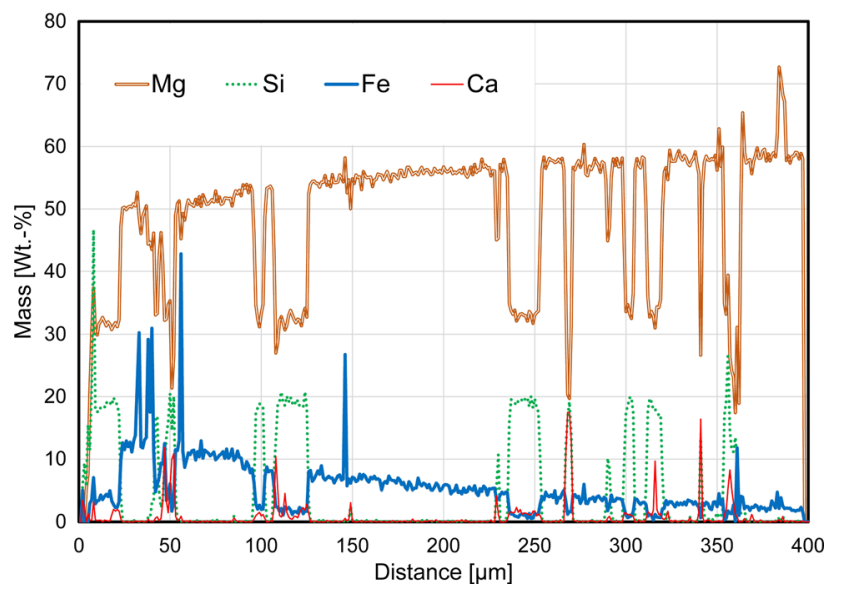

Fig. 8- Result of chemical analysis by the line scan indicated in Figure 7 across the corrosion zone.

remaining small pores (black areas). From zone 3 inwards, the free pore volume increases and zone 10 comprises unaffected refractory (15 pct porosity).

The microstructure of the slag/refractory interface was analyzed by a SEM (JEOL JSM IT-300 LV) equipped with an EDS analyser. The measurements were done with the following imaging conditions: $20 \mathrm{kV}$, scan time: $800 \mathrm{ls} /$ pixel, resolution: $2048 \times 2048$, and approximate counts on mapping: $8 \times 10^{5}$ on main element and $1.5 \times 10^{6}$ counts in sum.

Figure 8 depicts the chemical composition obtained from the line scan in Figure 7. The graph delineates in detail the decreasing Fe content of the refractory grains from zone 1 (slag infiltration zone) to zone 10 (deeper inside the refractory brick). The high silica content, combined with $\mathrm{Mg}, \mathrm{Ca}$, and $\mathrm{Fe}$ in the refractory, 
represents the chemical composition of monticellite $\left(\mathrm{MgCaSiO}_{4}\right)$ and forsterite $\left(\mathrm{Mg}_{2} \mathrm{SiO}_{4}\right)$. They exhibit $(\mathrm{Mg}+\mathrm{Fe}+\mathrm{Ca}) / \mathrm{Si}$ ratios of approximately 2 (mol. pct/mol. pct) (SEM/EDS analyses), which corresponds to the stoichiometry of olivine. Because of low aluminum contents, it was not possible to detect Al-containing spinel phases.

\section{RESULTS AND DISCUSSION}

The RCM simulation provides prediction of the progress of refractory corrosion. Depending on the used refractory and the slag compositions, the simulation model is able to calculate the corrosion of refractory material. The RCM calculates equilibria in 10 zones between slag/melt, solid oxides, and refractory material at defined temperatures along a theoretical pore. The assignment of temperatures to the zones by entering the temperature range allows a practice near calculation, which is one of the main differences to the existing literature. The separation of solid oxides (olivine, $\mathrm{MeO}$ and spinel) and melt after the equilibrium calculation (Figure 3 ) causes remaining solid oxides in a given zone and further transport of the melt to following zones. In comparison with existing models, which calculate the equilibrium between the same amount of slag and refractory, the RCM uses a more complex simulation. The amount and chemical composition of slag/melt, refractory material, and solid oxides depends directly on several input parameters (refractory porosity and refractory reaction part) and the current status of the simulation (the values change during the calculations). Moreover, through the iterative calculation, the RCM enables the simulation at different time steps of corrosion. The results of the RCM show good agreement with lab-scale investigations by using typical characteristics of slag and refractory from the ferronickel smelting. The only exception is iron, which spreads quickly without significant differences in the respective zones of the samples treated by HSM, whereas the RCM indicates the coexistence of magnesiowustite, (Fe, $\mathrm{Mg}) \mathrm{O}$, as a reaction product and unreacted refractory $(\mathrm{MgO})$ for individual zones.

The RCM corrosion graph in Figure 4 depicts different chemical wear results: zones 1-2 comprise magnesiowustite and melt. The main mechanism for the formation of magnesiowustite is the diffusion of Fe. In contrast to the results from the RCM, SEM/EDS characterization at room temperature detected olivine as a corresponding phase instead of an oxidic liquid (melt). A future extension of the model should enable a final cooling of all zones to room temperature for a direct comparison with analyzed micrographs.
In areas of lower temperatures, from zone 3 to zone 9 , the formation of olivine was detected. The solidification of the remaining melt in zone 9 can be explained by the comparable low temperature of this zone (Figure 4) despite the shift in its composition. An $\mathrm{Al}_{2} \mathrm{O}_{3}$-enriched melt penetrates zones 7-9, which are nearly unaffected, and forms solid spinel at lower temperatures. The monoxide and olivine phases, which precipitates first from the liquid, did not incorporate aluminum oxide. Consequently, its enrichment in the melt finally causes the formation of low amounts of spinel in the deeper zones of the refractory. However, because of low Al contents in the slag, it was not possible to detect compositions corresponding to Al-containing phases (spinel) (Figure 7).

The peak in the RCM graph (Figure 4) indicates olivine as a reaction product in zone 4 after approximately five calculation steps. At this point, olivine acts as a barrier against the penetration of the melt. In combination with other solid oxides, further infiltration is completely inhibited. This mechanism could be seen in the SEM/EDS mapping in the zones 5-8, where olivine phases in the pores prevent a deeper infiltration. Finally, the strongest corrosion occurred in zones 1 through 3 . The refractory in zone 1 is completely transformed into magnesiowustite, whereas zones 2 and 3 still contain some unaffected refractory. With additional simulation steps, the content of unreacted refractory in zone 2 is completely consumed (D in Figure 6).

\section{CONCLUSION}

Acidic, high melting point slags challenge refractory and ferronickel producers. To achieve an understanding of corrosion mechanisms at the slag/refractory interface in ferronickel manufacturing, the main topic of this work comprises the compilation of a refractory corrosion model, as well as its verification in practical investigations. The combination of the theoretical simulation method called RCM, accomplished by linking SimuSage $^{\mathrm{TM}}$ and FactSage ${ }^{\mathrm{TM}}$ with experimental investigation methods, provides excellent results regarding chemical corrosion of refractories in FeNi smelters. The refractory corrosion model considered the main slag oxides $\mathrm{SiO}_{2}, \mathrm{MgO}, \mathrm{FeO}, \mathrm{CaO}$, and $\mathrm{Al}_{2} \mathrm{O}_{3}$. The slag penetrates a virtual pore in the model and interacts with the magnesia-based refractory along its way. During the infiltration, the melt passes through equilibrium zones with stepwise declining temperature from one zone to the next, where on the one hand, magnesia is dissolved and on the other hand, stable phases like magnesiowustite, spinel, and olivine are formed. Depending on the zone location, the RCM results show a change of the element distribution in different phases, which causes enrichments of elements along the pore. 
The RCM provides information about the corrosion mechanism of a refractory brick during its application in a ferronickel smelter. Furthermore, the main reason for the simulation model is the forecast of the refractory wear by changing the process conditions in the smelter. That enables the operator to determine the service life of aggregates. In addition to the application in the industry, the support for the development of new refractory material is another important part. As a result of the fast and reliable simulation, the RCM provides rapid processing of high-quality refractory. For that purpose, additional work has to link the main model parameters, temperature levels of the individual zones, and refractory reaction part to detailed physical and chemical parameters such as pore size and distribution, diffusion rate, time, etc. So the results of a series of simulation runs with variations of the two main model parameter will be faced to practical measurements. Finally, this provides enough information for the adjustment of these model parameters to the, respectively, prevailing frame conditions regarding different refractory materials and process conditions. Beyond that the first results indicated that the distribution of iron within the particular zones (magnesiowustite and $\mathrm{Fe}$-free $\mathrm{MgO}$ ) did not correspond to the experimental results obtained by the HSM. This mismatch either can be resolved by the adjustment of the refractory reaction part or an extension of the model has to consider the variant behavior of $\mathrm{FeO}$. Further planned investigations will focus on this complicacy.

With a few changes of model structure and thermodynamic data from FactSage, it is possible to extend the use. Therefore, it is possible to use the refractory corrosion model also in different areas of metallurgy. Ongoing work focuses on different refractory substrates and slag systems for various metallurgical aggregates.

\section{ACKNOWLEDGMENTS}

The financial support by the Austrian Federal Ministry of Science, Research, and Economy and the National Foundation for Research, Technology, and Development is gratefully acknowledged.

\section{FUNDING}

Open access funding provided by Montanuniversität Leoben.
Open Access This article is licensed under a Creative Commons Attribution 4.0 International License, which permits use, sharing, adaptation, distribution and reproduction in any medium or format, as long as you give appropriate credit to the original author(s) and the source, provide a link to the Creative Commons licence, and indicate if changes were made. The images or other third party material in this article are included in the article's Creative Commons licence, unless indicated otherwise in a credit line to the material. If material is not included in the article's Creative Commons licence and your intended use is not permitted by statutory regulation or exceeds the permitted use, you will need to obtain permission directly from the copyright holder. To view a copy of this licence, visit http://creativecommons.org/licenses/by/4.0/.

\section{REFERENCES}

1. D. Gregurek, A. Ressler, V. Reiter, A. Franzowiak, A. Spanring, and T. Prietl: JOM, 2013, vol. 65 (11), pp. 1622-30.

2. C. Wagner, C. Wenzl, D. Gregurek, D. Kreuzer, S. Luidold, and H. Schnideritsch: Metall. Mater. Trans. B, 2017, vol. 48B (1), pp. 119-31.

3. C. Sagadin, S. Luidold, C. Wagner, A. Spanring, and T. Kremmer: $J O M, 2018$, vol. 70 (1), pp. 34-40.

4. J. Song, Y. Liua, X.L and Z. You: J. Mater. Res. Technol., 2020, vol. 9 (1), pp. 314-21.

5. J.P. Bennett and K. Kwong: Metall. Mater. Trans. B, 2011, vol. 42B, pp. 888-904.

6. W.E. Lee and S. Zhang: Int. Mater. Rev., 1999, vol. 44 (3), pp. 77-104.

7. J. Han, Y. Chung, and J. Park: Met. Mater. Int., 2019, vol. 25, pp. $1360-65$.

8. S. Chen, E. Jak and P.C. Hayes: ISIJ Int., 2005, vol. 45, pp. 1095-1100.

9. A. Luza, M. Braulioa, A. Martinezb, and V. Pandolfelli: Ceram. Int., 2011, vol. 37 (8), pp. 3109-16.

10. J. Berjonneau, P. Prigent, and J. Poirier: Ceram. Int., 2009, vol. 35 (2), pp. 623-35.

11. S. Zaho, B. Cai, H. Sun, G. Wang, H. Li, and X. Song: Int. J. Miner. Metall. Mater., 2016, vol. 23 (12), pp. 1458-65.

12. D. Hu, P. Liu and S. Chu: The Fourteenth International Ferroalloys Congress, 2014, pp. 115-21.

13. C.W. Bale, E. Belisle, P. Chartrand, S. Decterov, G. Eriksson, and K. Hack: Calphad Comput. Coupling Phase Diagr. Thermochem., 2009, vol. 33 (2), pp. 295-311.

14. A.P. Luz, F.C. Leite, M. Brito, and V. Pandolfelli: Ceram. Int., 2013, vol. 39, pp. 7507-15.

15. J. Han, J. Heo, and J. Park: Ceram. Int., 2019, vol. 45, pp. 1048191.

16. Stephan Petersen, K. Hack, P. Monheim and U. Pickartz: Int. J. Mater. Res., 2007, vol. 98 (10), pp. 946-53.

17. C.W. Bale, P. Chartrand, S. Decterov, G. Eriksson, and K. Hack: Calphad, 2002, vol. 26 (2), pp. 189-28.

Publisher's Note Springer Nature remains neutral with regard to jurisdictional claims in published maps and institutional affiliations. 